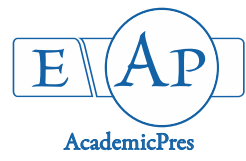

\title{
Zinc Influences Regeneration of Talinum portulacifolium Stem Cuttings in Nutrient Solution
}

\author{
Thangavelu MUTHUKUMAR*, Sarah JAISON, Selvam Dinesh BABU \\ Bharathiar University, Department of Botany, Root and Soil Biology Laboratory, Coimbatore 641046, Tamilnadu, \\ India;tmkum@yahoo.com ("corresponding author)
}

\begin{abstract}
Zinc $(\mathrm{Zn})$ is an essential micronutrient for plant growth and development, but toxic at high concentrations. The present study focused to underline the direct effect of different concentrations $(0-50 \mathrm{ppm})$ of $\mathrm{Zn}$ on the regeneration ability and morphological characteristics of Talinum portulacifolium stem cuttings in hydroponic solution over a period of 35 days without the interference of other soil factors. High concentrations of $\mathrm{Zn}(40-50 \mathrm{ppm})$ affected callusing, root initiation, root and shoot development to varying levels. At high concentrations, Zn caused stem decay, stunting and browning of roots, wilting, withering and necrotic spots on leaves. Increasing concentrations of $\mathrm{Zn}$ inversely affected the lateral shoot development, stem elongation, leaf, root numbers and total root length of the stem cuttings. Though $\mathrm{Zn}$ had no significant influence on fresh or dry weights of stem, low concentration (15 ppm) of $\mathrm{Zn}$ increased the fresh and dry weights of leaves by $11.17 \%$ and $26.79 \%$ respectively, compared to $0 \mathrm{ppm}$ and with $77.06-243.80 \%$ and $47.92-255.00 \%$ compared with those raised in $20-50 \mathrm{ppm}$. $\mathrm{Zn}$ concentrations $>10 \mathrm{ppm}$ reduced the root fresh weight by $28.57-90.47 \%$ and dry weight by $27.27-90.91 \%$ than those at $0 \mathrm{ppm}$. The $\mathrm{Zn}$ content in leaves and stems increased linearly with increasing concentrations of $\mathrm{Zn}$ and ranged from 1.09-125.62 ppm and 1.00-110.26 in stems and leaves respectively. The tolerance index varied between 81 and 138 for different concentrations of $\mathrm{Zn}$. The results of the study clearly indicate that high concentrations of $\mathrm{Zn}$ inhibit the regeneration of $T$. portulacifolium stem cuttings.
\end{abstract}

Keywords: growth; heavy metals; hydroponics; rooting

\section{Introduction}

Heavy metals (HMs) are exceptionally dangerous environmental pollutants which are toxic to plants and animals even at extremely low concentrations. Contamination by toxic HMs is of a great concern worldwide because of their long lasting toxic effect on the environment (Tchounwou et al., 2012). Consumption of crops and vegetables grown in HMs contaminated soils or drinking HMs contaminated water directly exposes humans to HMs (Nagajyoti et al., 2010; Balkhair and Ashraf, 2016). Being the member of Group-II of the periodic table, is an essential element for plant and animal metabolism and exists in the form of its oxides, sulphides and chlorides in the soil (Das and Green, 2013). On the other hand concentrations of $\mathrm{Zn}$ higher than $0.2 \mathrm{mg} / \mathrm{g}$ in plant dry matter can be toxic (Tsonev and Lidon, 2012). Excessive presence of $\mathrm{Zn}$ may result in leaf chlorosis (Cobbett and Goldsbrough, 2002) and also affect photosynthesis by interfering with the development of pigments, stomatal functioning, enzyme activities and electron transport through alterations in membrane architecture (Rout and Das, 2003). Zinc toxicity results in respiratory and gastrointestinal disorders in humans (Plum et al., 2010). Anthropogenic activities like mining, purification of $\mathrm{Zn}$, excessive use of agrochemicals containing $\mathrm{Zn}$ and the use of untreated sewage water for irrigating agricultural crops are the major sources of $\mathrm{Zn}$ pollution (Lone et al., 2008; Tsonev and Lidon, 2012).

Remediation of $\mathrm{Zn}$ contaminated soils is receiving more attention recently both from the governmental bodies as well as the public, especially in developing countries (Yanez et al., 2002). Technologies involving plants that require long treatment period are used for removing HMs like $\mathrm{Zn}$ from areas where the concentrations of these metals are low, soils are shallow or when the medium is water (Li et al., 2014). However, when using a plant based system it is important to understand the toxic effects of $\mathrm{Zn}$ on the plants and also the ability of plants to grow or regenerate in such toxic environments.

Growing plants in nutrient solutions is a convenient method for studying plants under laboratory conditions and 
is termed as hydroponics (Conn et al., 2013). Manipulation of nutrient profile or incorporation of elements like HMs is easy in hydroponics than in the soil. Several factors like the physicochemical properties, total content of the HMs, microbial activities and plant species can affect the bioavailability of HMs in the soil (Jones, 1982). Therefore, HMs studies are often conducted in hydroponic system to better understand the effects of individual or combinations of HMs on plants as there is no interference from other soil factors (Shahid et al., 2014; Fasani et al., 2018). Moreover, the advantage of hydroponic culture includes reduction in the growth period, duration of treatments and also the space required to carry out the study ( $\mathrm{Niu}$ et al., 2007). Hydroponics also allows us to understand the ability of plants to absorb, concentrate or precipitate toxic metals from contaminated growing medium (Dushenkov et al., 1995).

Many plants are propagated vegetatively due to their ease, quick regeneration and production of true-to-type plants. Several factors are shown to affect regeneration of stem cuttings (Hassanein, 2013). These include cutting material, environmental conditions and rooting media. The influence of $\mathrm{HMs}$ on the regeneration of stem cuttings have been examined in a wide range of plant species and different HMs (Rajkumar et al., 2009; Andrades-Moreno et al., 2013; Iori et al., 2015; Wang et al., 2016). However, information on the influence of $\mathrm{Zn}$ on the regeneration potential of stem cuttings is very limited compared to other HMs. A study on the interactive effect of $\mathrm{Zn}$ and $\mathrm{Cu}$ on the regeneration potential of Portulaca oleracea $\mathrm{L}$., stem cuttings revealed that the toxicity of $\mathrm{Zn}$ was found to be higher with increasing concentrations of $\mathrm{Cu}$ (Jayanthi et al., 2015). A high concentration of $\mathrm{Zn}$ not only reduces the rooting capacity, but also alters metallothione gene expression in Populus alba L. cv. 'Villafranca' (Castiglione et al., 2007).

Talinum portulacifolium (Forssk.) Asch. ex Schweinf., of the plant family Portulacaceae is an erect under-shrub native to Africa (Lansdown, 2013). Though T. portulacifolium is categorized as a species of least concern with no major threats according to the IUCN red list of threatened species (Lansdown, 2013), the leaves and roots of this plant is used as food and an aphrodiasic (Miller and Morris, 2004). The extracts prepared from the leaves of $T$. portulacifolium possess antihyperglycemic and antioxidant activities (Babu et al., 2009). This plant can be propagated through stem cuttings (Kumar and Prasad, 2010).

The main objective of the present study was to investigate the influence of different concentrations of $\mathrm{Zn}$ on regeneration potential of $T$. portulacifolium stem cuttings and the ability of this plant species to accumulate $\mathrm{Zn}$.

\section{Materials and Methods}

Experimental design and preparation of metal concentrations

The influence of different concentrations of soluble form of $\mathrm{Zn}$ on the regeneration ability of $T$. portulacifolium stem cuttings was studied using nutrient solutions. Stem cuttings of $T$. portulacifolium of approximately equal length and thickness (12 cm long and $1 \mathrm{~cm}$ thick) were taken from healthy plants growing under natural conditions in uncontaminated soil at Bharathiar University Campus, Coimbatore, India using a sterile stainless steel sharp knife.

$\mathrm{ZnSO}_{4} 7 \mathrm{H}_{2} \mathrm{O}$ formed the source of $\mathrm{Zn}$. Hogland nutrient solution $\left(\mathrm{KNO}_{3}, \mathrm{Ca}\left(\mathrm{NO}_{3}\right)_{2} 4 \mathrm{H}_{2} \mathrm{O}, \mathrm{MgSO} \mathrm{OH}_{2} \mathrm{O}\right.$, $\mathrm{NH}_{4} \mathrm{H}_{2} \mathrm{PO}_{4}, \mathrm{MnCl}_{2} 4 \mathrm{H}_{2} \mathrm{O}, \mathrm{H}_{3} \mathrm{BO}_{3}, \mathrm{MoO}_{3}, \mathrm{ZnSO}_{4} 7 \mathrm{H}_{2} \mathrm{O}$, $\mathrm{CuSO}_{4} 5 \mathrm{H}_{2} \mathrm{O}, \quad \mathrm{FeSO}_{4} 7 \mathrm{H}_{2} \mathrm{O}$ ) without or with different concentrations of $\mathrm{Zn}$ was prepared by dissolving known quantities of $\mathrm{ZnSO}_{4}$ in Hoagland nutrient solutions to yield the required concentrations of 5 ppm, 10 ppm, 15 ppm, 20 ppm, 25 ppm, 30 ppm, 35 ppm, 40 ppm, 45 ppm and 50 ppm (Hoagland and Arnon, 1950). Hoagland nutrient solution without $\mathrm{Zn}(0 \mathrm{ppm})$ served as the medium for the growth of control plants.

The experiment was performed in $200 \mathrm{ml}$ capacity glass containers each containing $100 \mathrm{ml}$ of known concentration of $\mathrm{Zn}$. Only the lower part of the twig (approximately one to two $\mathrm{cm}$ ) was immersed in the $\mathrm{Zn}$ solution. The containers were covered with aluminium foil to prevent the growth of algae and development of chlorophyll in roots. There were five replicates for all concentration of $\mathrm{Zn}$ including control. Two cuttings were maintained per container. The solutions were replaced every $7^{\text {th }}$ day throughout the experimental period. The cuttings were maintained at room temperature $\left(27 \pm 4{ }^{\circ} \mathrm{C}\right)$ with $14 \mathrm{~h}$ day $/ 10 \mathrm{~h}$ dark period at light intensity of 300 to $350 \mu \mathrm{mol}$ $\mathrm{m}^{-2} \mathrm{~s}^{-1}$.

\section{Measurements of plant growth}

The treated cuttings were first observed 7 days after the initiation of the experiment and later regularly at weekly intervals for about 35 days. The regeneration parameters observed were sprouting, root initiation, number of shoots and roots, number of leaves developed, root length, callusing, and any stem decay.

Harvest

The plants were harvested after 35 days of the initiation of the experiment, separated into shoot and root parts, and fresh weight was measured. The shoots and roots were then dried at $78^{\circ} \mathrm{C}$ for 48 hours in a hot air oven to obtain a stable dry weight.

\section{Plant elemental analysis}

Dried plant samples (leaves and stem) were ground into a fine powder and wet acid digested with $\mathrm{HNO}_{3}, \mathrm{H}_{2} \mathrm{SO}_{4}$, and $\mathrm{HClO}_{4}$ in the ratio of 9:2:1 (Antosiewicz, 1993; Piper, 1966) for quantifying total $\mathrm{Zn}$ concentration in plant tissues. The $\mathrm{Zn}$ content in the plant digestates were measured using an Atomic Absorption Spectrophotometer (Varian Techtran Spectr AA 10/20 BQ, Australia). Due care was taken to avoid metal contamination during the entire process of harvesting, washing, drying and grinding.

\section{Tolerance index $(\mathrm{Ti})$}

Tolerance index $(\mathrm{Ti})$, the ability of a plant to grow in the presence of a given concentration of $\mathrm{Zn}$ was calculated according to Wilkins (1978) using the formula:

$\mathrm{Ti}=($ Dry weight of plants raised in Zn solution/ Dry weight of plants raised in control solution) $\times 100$ 
532

\section{Statistical analysis}

Mean values of morphological growth parameters were calculated from five replicates in each concentration. The significant variation among means was assessed using Analysis of Variance (ANOVA) after testing for homogeneity (Levene's test). Duncan's Multiple Range Test (DMRT) was performed to separate means of variables where ANOVA was found to be significant. Pearson's correlation analysis and regression analysis was used to assess the relation of increasing $\mathrm{Zn}$ concentration on growth and $\mathrm{Zn}$ concentrations in stem cuttings.

\section{Results}

Effect of $Z$ n on shoot and root regeneration and callusing

Sprouts started to emerge on the stem cuttings on the third day, but root initiation was observed only on the sixth day in 0 and 5 ppm Zn solution (Table 1). Root initiation was further delayed with increasing concentrations (10-50 $\mathrm{ppm})$ of $\mathrm{Zn}$ in the solution. The root initiation was delayed by 7 days in concentrations $>20 \mathrm{ppm}$ and was further delayed by 13 days in higher concentrations of 40-50 ppm compared to control. The callus formation (Fig. 1) was maximum at $35 \mathrm{ppm}$, followed by control and callusing was minimum at $45 \mathrm{ppm}$. Though $\mathrm{Zn}$ concentrations significantly influenced root initiation and callus formation, it did not affect sprouting (Table 1). The delay in sprouting and root initiation was linearly related to increasing concentrations of $\mathrm{Zn}$. However, variations in callus formation were not related to concentrations of $\mathrm{Zn}$ in the nutrient solution (Table 1).

\section{Morphological changes when exposed to various concentrations of $\mathrm{Zn}$}

The stem cuttings showed various morphological changes in response to the exposure to different concentrations of $\mathrm{Zn}$. Increasing concentrations of $\mathrm{Zn}$ caused wilting and withering of leaves (Fig. 2). At higher concentrations (40 ppm and above), $\mathrm{Zn}$ caused browning and decay of the stem cuttings.

Table 1. Days for initiation of shoots, roots and callus formation in the stem of Talinum portulacifolium exposed to various concentrations of Zinc

\begin{tabular}{cccc}
\hline Concentration $(\mathrm{ppm})$ & Sprouting (days) & Root initiation (days) & Callus formation (cm) \\
\hline 0 & $2.6 \mathrm{a}$ & $6.0 \mathrm{e}$ & $2.06 \mathrm{a}$ \\
5 & $2.8 \mathrm{a}$ & $6.0 \mathrm{e}$ & $1.76 \mathrm{abc}$ \\
10 & $2.8 \mathrm{a}$ & $6.2 \mathrm{e}$ & $1.71 \mathrm{~cd}$ \\
15 & $2.8 \mathrm{a}$ & $6.4 \mathrm{de}$ & $1.86 \mathrm{ab}$ \\
20 & $2.8 \mathrm{a}$ & $6.8 \mathrm{de}$ & $1.80 \mathrm{bcd}$ \\
25 & $2.8 \mathrm{a}$ & $8.4 \mathrm{~cd}$ & $1.64 \mathrm{de}$ \\
30 & $3.0 \mathrm{a}$ & $9.2 \mathrm{bc}$ & $1.86 \mathrm{ab}$ \\
35 & $3.0 \mathrm{a}$ & $10.6 \mathrm{~b}$ & $2.09 \mathrm{a}$ \\
40 & $3.0 \mathrm{a}$ & $13.2 \mathrm{a}$ & $1.56 \mathrm{e}$ \\
50 & $3.0 \mathrm{a}$ & $13.0 \mathrm{a}$ & $1.40 \mathrm{f}$ \\
$\mathrm{F}_{10,44}$ & $3.0 \mathrm{a}$ & $13.0 \mathrm{a}$ & $1.52 \mathrm{ef}$ \\
$\mathrm{r} \dagger$ & $<1 \mathrm{~ns}$ & $14.17^{* *}$ & $2.69^{*}$ \\
\hline
\end{tabular}

$*, * * * * *$ Significant at $\mathrm{P}<0.05, \mathrm{P}<0.01, \mathrm{P}<0.001$ and $n s$, not significant

Mean in a column followed by a same letter $(s)$ are not significantly $(\mathrm{P}>0.05)$ different according to Duncan's Multiple Range Test.
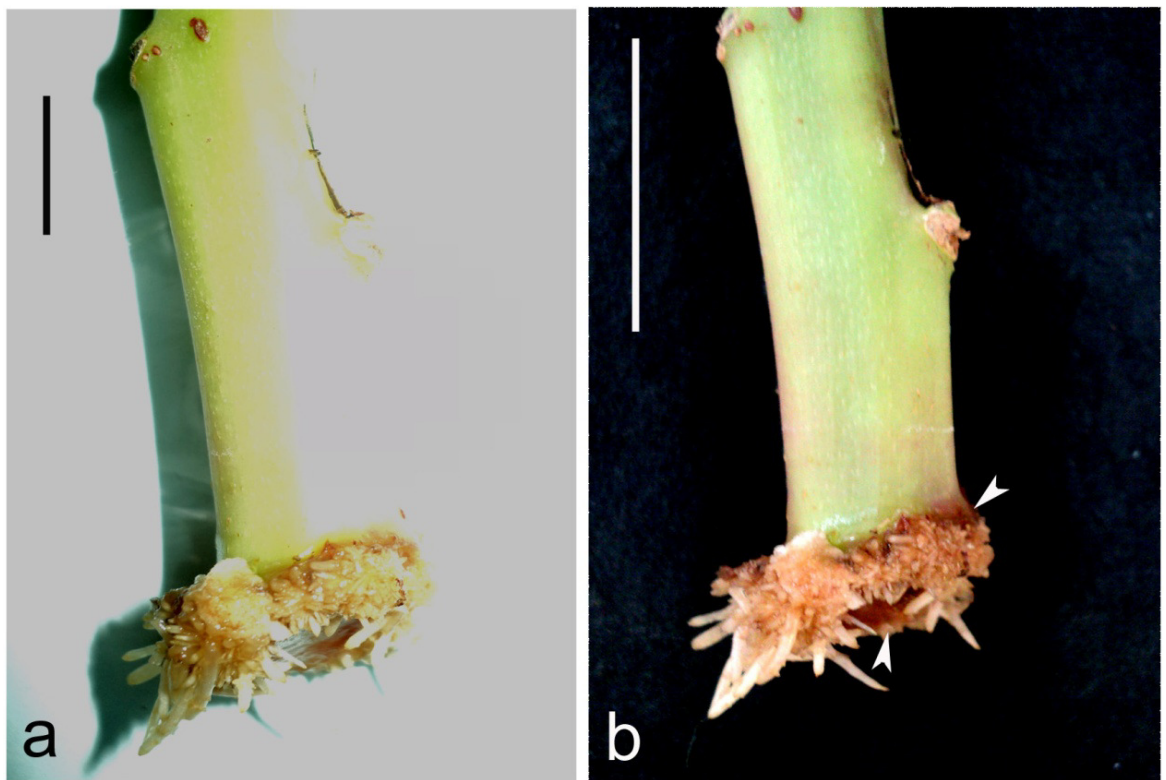

Fig. 1. Callus formation of Talinum portulacifolium stem cutting exposed to (a) $10 \mathrm{ppm}$ and (b) 40 ppm of Zinc. Note the browning and initiation of decay at the cut surface (white arrow heads) in image b. Scale bars $=1 \mathrm{~cm}$. 
The decay started at the cut surface and spread upwards. At the maximum concentration (50 ppm) $\mathrm{Zn}$ caused withering off the leaves and the narrowing of leaves occurred at concentrations of $30-50 \mathrm{ppm}$.

\section{Influence of $Z n$ on the morphological parameters \\ Number of lateral shoots}

Increasing concentrations of $\mathrm{Zn}$ significantly influenced the number of lateral shoots on $T$. portulacifolium stem cuttings. Nevertheless, neither growth period nor its interaction with different concentrations of $\mathrm{Zn}$ significantly influenced the number of lateral shoots developed on the stem cuttings (Table 2 ).

The highest number of lateral shoots was observed in 0 , $10,30,35$ and $45 \mathrm{ppm}$ on the seventh day. However, the number of lateral shoots was 7.14-17.86\% lower in other treatments. At $14^{\text {th }}$ day, the number of lateral shoots in stem cuttings raised in different concentrations of $\mathrm{Zn}$ was 6.25$31.25 \%$ lower than the control stem cuttings. There was no lateral shoot formation after the $14^{\text {th }}$ day of the initiation of the study except for $35^{\text {th }}$ day where cuttings raised in 45 ppm of $\mathrm{Zn}$ had $7.14 \%$ more lateral shoots than at $28^{\text {th }}$ day (Table 2).

\section{Elongation of stem cuttings}

The length of $T$. portulacifolium stem cuttings significantly varied with growth period and concentrations of $\mathrm{Zn}$ in the nutrient solution. But the interaction between these factors was not significant. Though the influence of increasing concentrations of $\mathrm{Zn}$ on the length of $T$. portulacifolium stem cuttings was not linear initially (seventh day), it was apparent during later stages of cutting development.

Different concentrations of $\mathrm{Zn}$ increased the length of the cuttings by $8.16-65.30 \%$ at the seventh day except for 25 $\mathrm{ppm}, 35 \mathrm{ppm}$ and $50 \mathrm{ppm}$ where the length of the cuttings was $4.05-13.95 \%$ lower than control. At 5 ppm concentration, $\mathrm{Zn}$ increased the length of the cutting by $8.27-15.85 \%$ between $15^{\text {th }}$ and $35^{\text {th }}$ day, whereas cuttings in other concentrations of $\mathrm{Zn}$ had reduced shoot length compared to control during the same period. Although cuttings in $15 \mathrm{ppm} \mathrm{Zn} \mathrm{had} \mathrm{reduced} \mathrm{shoot} \mathrm{length} \mathrm{compared}$ to control during initial stages, a $1.75 \%$ and $2.69 \%$ increase in shoot length compared to control was evident during $28^{\text {th }}$ and $35^{\text {th }}$ day (Table 2).

\section{Leafnumbers}

Growth period, as well as concentrations of $\mathrm{Zn}$ significantly influenced the number of leaves on $T$. portulacifolium stem cuttings. However the interaction day $x$ treatment for leaf number was not significant. The linear decline in the number of leaves with increasing concentrations of $\mathrm{Zn}$ was evident during different stages of cutting development except for the seventh and $28^{\text {th }}$ day.

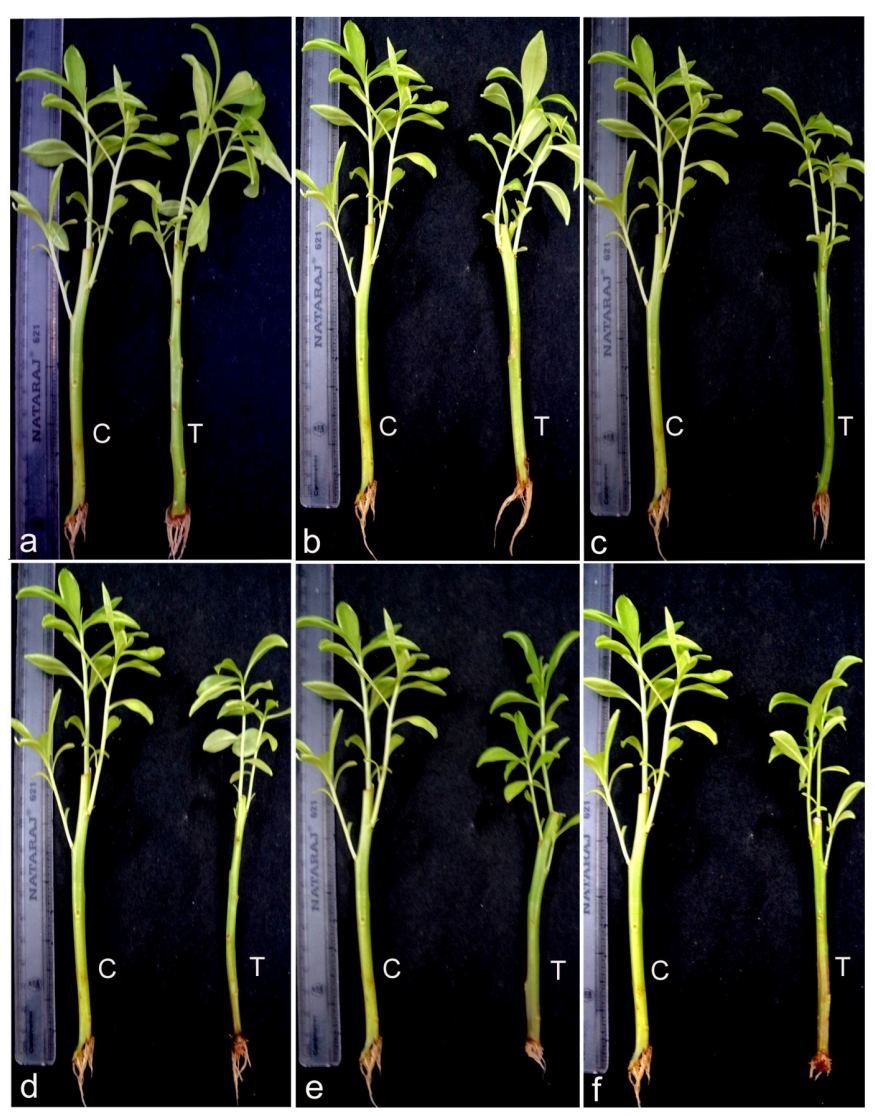

Fig. 2. Morphological aspects of Talinum portulacifolium exposed to 5 ppm (a), 15 ppm (b), 30 ppm (c), 40 ppm (d), 45 ppm (e) and $50 \mathrm{ppm}$ (f) of Zinc. C, Control and T, Treatment 
Muthukumar T et al / Not Sci Biol, 2018, 10(4):530-539

534

Table 2. Influence of different concentrations of $\mathrm{Zn}$ on the regeneration of Talinum portulacifolium stem cuttings over a period of 35 days

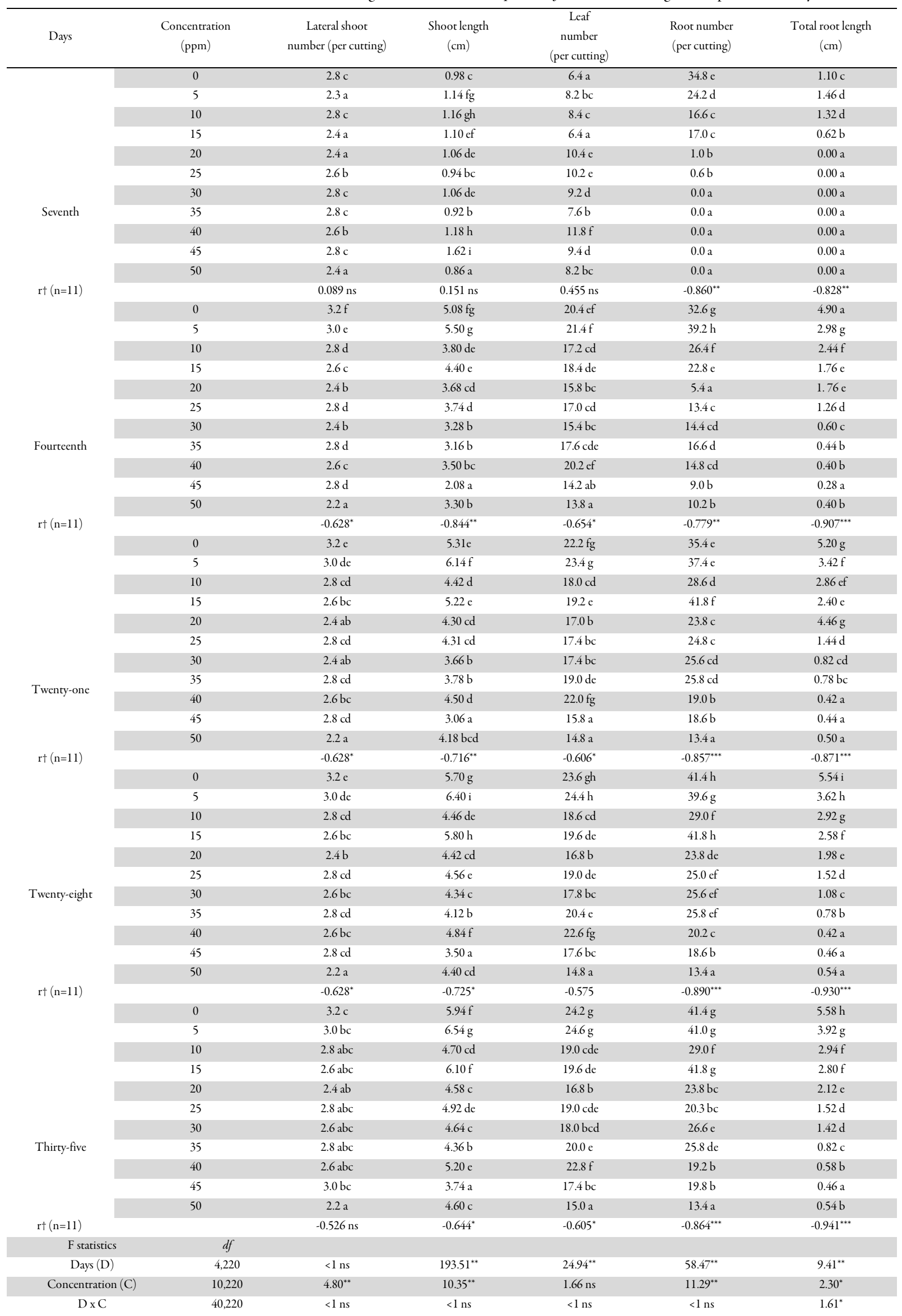

†Pearson's correlation coefficient. ${ }^{* * * *},{ }^{* * *}$ Significant at $\mathrm{P}<0.05, \mathrm{P}<0.01, \mathrm{P}<0.001$ and ns, not significant.

Mean in a column for a day followed by a same letter $(s)$ are not significantly $(\mathrm{P}>0.05)$ different according to Duncan's Multiple Range Test. 
The number of leaves on stem cuttings raised in $15 \mathrm{ppm}$ of $\mathrm{Zn}$ was similar to control at the seventh day, while cuttings raised in other concentrations of $\mathrm{Zn}$ had 18.75$84.38 \%$ more leaves than control. Likewise, cuttings raised in $5 \mathrm{ppm}$ of $\mathrm{Zn}$ had $1.65-5.41 \%$ more leaves than control during $14^{\text {th }}$ to $35^{\text {th }}$ day of growth. The number of leaves in other concentrations of $\mathrm{Zn}$ was $0.98-32.35 \%, 0.90-33.33 \%$, 4.24-37.29\%, and 5.79-38.02\% lower than the respective controls respectively during $14^{\text {th }}, 21^{\text {st }}, 28^{\text {th }}$ and $35^{\text {th }}$ days of growth.

\section{Rooting}

Different concentrations of $\mathrm{Zn}$ and growth period significantly influenced the number of roots on $T$. portulacifolium stem cuttings. The decrease in root numbers was inversely related to increasing concentrations of $\mathrm{Zn}$ in the nutrient solution, but the interaction among these factors was not significant.

At the seventh day, different concentrations of $\mathrm{Zn}$ reduced root numbers by $30.46-100 \%$ when compared to control. Contrarily, $5 \mathrm{ppm}$ of $\mathrm{Zn}$ increased the number of roots in $T$. portulacifolium stem cuttings by $20.25 \%$ and $5.65 \%$ at $14^{\text {th }}$ and $21^{\text {st }}$ days respectively. An $18.08 \%, 0.97 \%$ and $0.97 \%$ increase in root number than control was also evident in cuttings raised in the presence of $10 \mathrm{ppm}$ of $\mathrm{Zn}$ during $21^{\text {st }}, 28^{\text {th }}$ and $35^{\text {th }}$ days of growth. The number of roots in other concentrations of $\mathrm{Zn}$ was $19.02-83.44 \%$, 19.21-62.15\%, 4.35-67.63\%, and 0.97-67.63\% lower than the respective controls during $14^{\text {th }}, 21^{\text {st }}, 28^{\text {th }}$ and $35^{\text {th }}$ days of growth (Table 2).

Increasing concentrations of $\mathrm{Zn}$ inversely affected root length of $T$. portulacifolium stem cuttings. However, the root length of cuttings grown in the presence of $5 \mathrm{ppm}$ and $10 \mathrm{ppm}$ was $0.36 \%$ and $0.22 \%$ higher than the control at the seventh day. The roots of $T$. portulacifolium stem cuttings were $0.48 \%$ shorter at $15 \mathrm{ppm} \mathrm{Zn}$. Different concentrations of $\mathrm{Zn}$ and growth period significantly affected root length of T. portulacifolium stem cuttings. The interaction day $\times$ treatment was also significant for root length. The roots of T. portulacifolium stem cuttings raised in different concentrations of $\mathrm{Zn}$ was 39.18-94.29\%, 14.23-91.92\%, $34.66-92.42 \%$, and $29.75-91.76 \%$ shorter than the respective controls during $14^{\text {th }}, 21^{\text {st }}, 28^{\text {th }}$ and $35^{\text {th }}$ days of growth.

\section{Fresh and dry weights}

Significant differences existed for fresh weights of leaves, and roots of $T$. portulacifolium stem cuttings raised in different concentrations of $\mathrm{Zn}$ (Table 3). In contrast, the variation in fresh weight of stems was not significant. Leaf dry weight significantly varied among treatments for cuttings grown in different concentrations of $\mathrm{Zn}$. Nevertheless, no such significant variation exited for stem dry weight. Different concentrations of $\mathrm{Zn}$ significantly influenced the root dry weights. Though different concentrations of $\mathrm{Zn}$ negatively influenced the leaf fresh and dry weights, such an influence was only evident for fresh weight of roots (Table 3).

Low concentration of $\mathrm{Zn}$ increased the fresh and dry weights of leaves which were respectively $11.17 \%$ and $26.79 \%$ higher than the control and $77.06-243.80 \%$ and 47.92-255.01\% higher than those raised in other concentrations of $\mathrm{Zn}$. Fresh and dry weights of roots of $T$. portulacifolium stem cuttings raised in different concentrations of $\mathrm{Zn}$ were $28.57-90.47 \%$ and $27.27-90.91 \%$ lower than the control root cuttings (Table 3 ).

\section{Tolerance index}

Maximum tolerance index $(\mathrm{Ti})$ was observed for stem cutting raised in $40 \mathrm{ppm}$ of $\mathrm{Zn}$ which was $9.88-69.07 \%$ higher than those raised in other concentrations of $\mathrm{Zn}$. Similarly, cuttings raised in $45 \mathrm{ppm}$ of $\mathrm{Zn}$ had the least $\mathrm{Ti}$ which was $4.28-41.25 \%$ lower than cuttings raised in other concentrations of Zn (Fig. 3).

\section{Accumulation of $Z n$ in the stem and leaves}

Significant variation $(\mathrm{P}<0.001)$ existed between the accumulation of $\mathrm{Zn}$ in the stem $\left(\mathrm{F}_{10,44}=289.111\right)$ and leaf $\left(\mathrm{F}_{10,44}=188.887\right)$ of $T$. portulacifolium at various concentrations of $\mathrm{Zn}$ (Fig. 4). A linear increase in the accumulation of $\mathrm{Zn}$ was observed in the leaves and stems of T. portulacifolium, with the highest $\mathrm{Zn}$ accumulation occurring at $40 \mathrm{ppm}$ in both the plant parts (Fig. 4).

Table 3. Fresh and dry weight of leaves, stem and roots of Talinum portulacifolium exposed to different concentrations of Zinc after 35 days of growth

\begin{tabular}{|c|c|c|c|c|c|c|}
\hline \multirow[b]{2}{*}{ Concentration (ppm) } & \multicolumn{3}{|c|}{ Fresh weight (g) } & \multicolumn{3}{|c|}{ Dry weight (g) } \\
\hline & Leaf & Stem & Root & Leaf & Stem & Root \\
\hline 0 & $1.271 \mathrm{a}$ & $4.13 \mathrm{ab}$ & $0.042 \mathrm{a}$ & $0.056 \mathrm{ab}$ & $0.211 \mathrm{a}$ & $0.011 \mathrm{a}$ \\
\hline 5 & $1.413 \mathrm{a}$ & $4.87 \mathrm{ab}$ & $0.030 \mathrm{~b}$ & $0.071 \mathrm{a}$ & $0.264 \mathrm{a}$ & $0.008 \mathrm{bc}$ \\
\hline 10 & $0.72 \mathrm{~b} \mathrm{c}$ & $3.48 \mathrm{ab}$ & $0.016 \mathrm{c}$ & $0.044 \mathrm{c}$ & $0.208 \mathrm{a}$ & $0.004 \mathrm{cde}$ \\
\hline 15 & $0.798 \mathrm{~b}$ & $3.93 \mathrm{ab}$ & $0.018 \mathrm{c}$ & $0.042 \mathrm{~cd}$ & $0.304 \mathrm{a}$ & $0.005 \mathrm{~cd}$ \\
\hline 20 & $0.552 \mathrm{bc}$ & $3.68 \mathrm{ab}$ & $0.010 \mathrm{c}$ & $0.031 \mathrm{~cd}$ & $0.296 \mathrm{a}$ & 0.003 de \\
\hline 25 & $0.522 \mathrm{bc}$ & $4.15 \mathrm{ab}$ & $0.022 \mathrm{c}$ & $0.022 \mathrm{~cd}$ & $0.202 \mathrm{a}$ & $0.006 \mathrm{~cd}$ \\
\hline 30 & $0.588 \mathrm{bc}$ & $5.21 \mathrm{ab}$ & $0.012 \mathrm{c}$ & $0.028 \mathrm{~cd}$ & $0.252 \mathrm{a}$ & 0.003 de \\
\hline 35 & $0.508 \mathrm{bc}$ & $4.24 \mathrm{ab}$ & $0.004 \mathrm{c}$ & $0.043 \mathrm{bc}$ & $0.262 \mathrm{a}$ & $0.001 \mathrm{e}$ \\
\hline 40 & $0.672 b c$ & $5.47 \mathrm{a}$ & $0.010 \mathrm{c}$ & $0.048 \mathrm{~cd}$ & $0.332 \mathrm{a}$ & 0.003 de \\
\hline 45 & $0.411 \mathrm{c}$ & $3.65 \mathrm{ab}$ & $0.004 \mathrm{c}$ & $0.034 \mathrm{~d}$ & $0.218 \mathrm{a}$ & $0.001 \mathrm{e}$ \\
\hline 50 & $0.460 \mathrm{c}$ & $3.94 \mathrm{~b}$ & $0.008 \mathrm{c}$ & $0.020 \mathrm{~cd}$ & $0.218 \mathrm{a}$ & 0.002 de \\
\hline $\mathrm{F}_{10,44}$ & $12.10^{* *}$ & $1.13 \mathrm{~ns}$ & $8.31^{* *}$ & $5.81^{* *}$ & $<1 \mathrm{~ns}$ & $9.56^{* *}$ \\
\hline $\mathrm{r} \dagger(\mathrm{n}=11)$ & $-0.802^{* *}$ & $0.106 \mathrm{~ns}$ & $-0.810^{* *}$ & $-0.641^{*}$ & $0.076 \mathrm{~ns}$ & $0.500 \mathrm{~ns}$ \\
\hline
\end{tabular}

†Pearson's correlation coefficient

${ }^{* * *}$ Significant at $\mathrm{P}<0.05, \mathrm{P}<0.01$ and $\mathrm{ns}$, not significant.

Mean in a column for a zinc concentration followed by a same letter $(s)$ are not significantly $(\mathrm{P}>0.05)$ different according to Duncan's Multiple Range Test. 
536

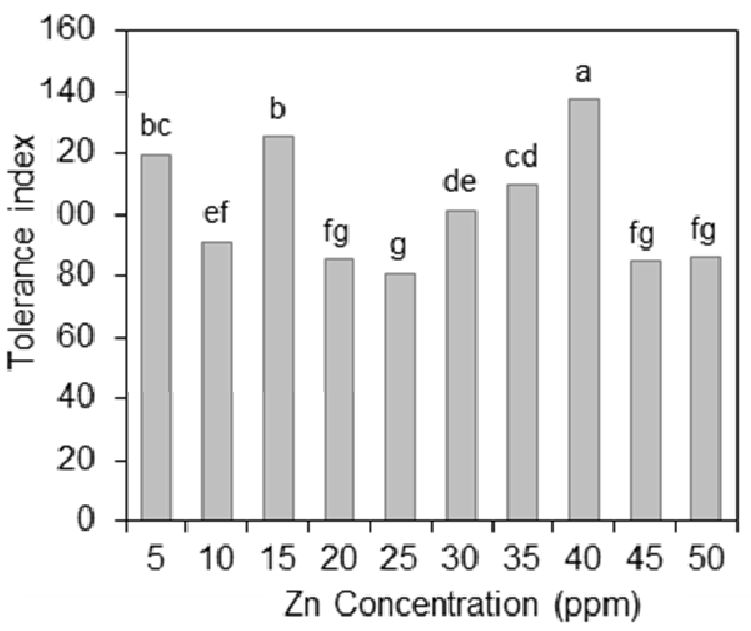

Fig. 3. Tolerance index of Talinum portulacifolium exposed to different concentrations of Zinc. Bars bearing same letter(s) are not significantly $(\mathrm{P}>0.05)$ different according to Duncan's Multiple Range Test
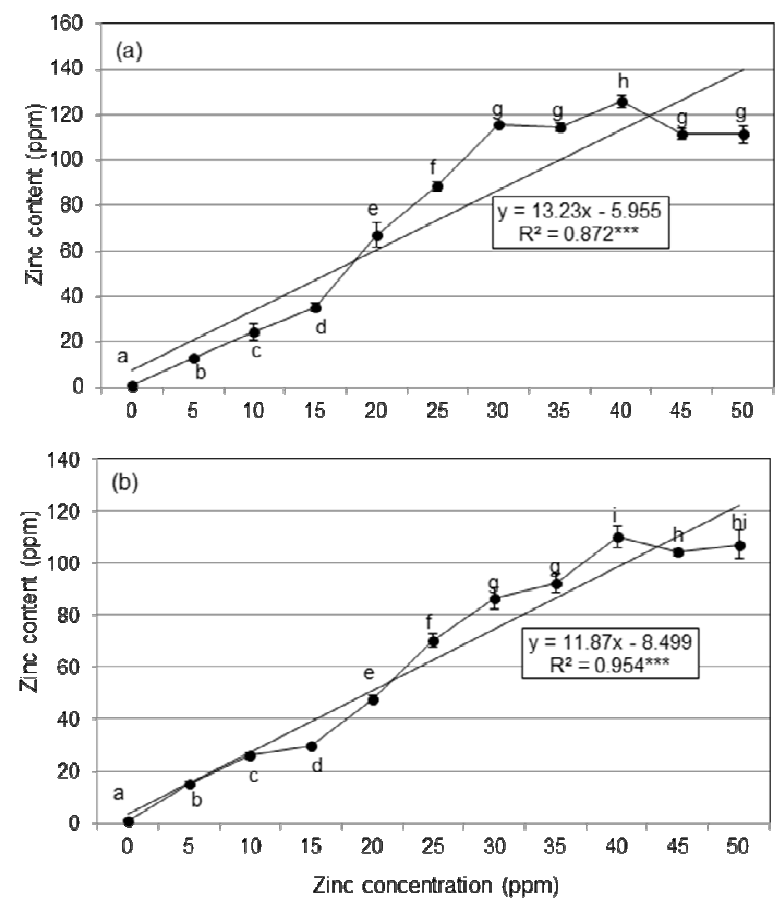

Fig. 4. Accumulation of Zinc in the stem (a) and leaf (b) of Talinum portulacifolium in nutrient solution. Error bar indicates \pm standard error. Points followed by same letters are not significantly different according to DMRT $(\mathrm{P}>0.05)$. ${ }^{* * *}$ Significant at $\mathrm{P}<0.001$.

\section{Discussion}

The results of the present study clearly showed that increasing concentrations of $\mathrm{Zn}$ in the nutrient solution affected the regeneration of $T$. portulacifolium stem cuttings and the inhibition of development was at many instances proportional to the increase in concentrations of $\mathrm{Zn}$ in the nutrient solution. Root initiation on $T$. portulacifolium stem cuttings was delayed by almost seven to eight days in higher concentrations of $\mathrm{Zn}$. This is similar to the results of a study where higher concentrations of $\mathrm{Cu}$ delayed root initiation in P. oleracea (Mohanapriya et al., 2006). The inhibitory effect of HMs on the plant hormone metabolic pathways can induce changes in the production of key plant growth hormones like auxins and cytokinins that are responsible for rooting (Vysotskaya et al., 2007). This could have delayed rooting as observed in $T$. portulacifolium stem cuttings. A moderate delay was observed in the development of leaves, as the leaves appeared on $2^{\text {nd }}$ to $3^{\text {rd }}$ day on the stem cuttings, which is in accordance with the results obtained by Mohanapriya et al. (2006) in P. oleracea. Sprouting of the stem cuttings even at the highest concentrations of $\mathrm{Zn}$ tested indicates the lack of critical concentration of $\mathrm{Zn}$ accumulation at the site of sprouting in the stem. Moreover, as roots are in direct contact with the metal solution, roots exhibit symptoms of metal interaction much earlier than shoots (Mohanapriya et al., 2006).

The decrease in the number of shoot buds and leaves with increasing concentrations of $\mathrm{Zn}$ may be attributed to the effect of $\mathrm{Zn}$ on the phytohormone cytokinin. Cytokinin is known to promote axillary and adventitious shoot formation due to its effect on cell division and shoot morphogenesis (Wang et al., 2017). Similar findings were also reported for $P$. oleracea stem cuttings when raised on different concentrations and sources of copper $(\mathrm{Cu})$ (Mohanapriya et al., 2006) and for Talinum triangulare (Jacq.) Willd., stem cuttings exposed to various concentrations (Rajkumar et al., 2009).

At higher concentrations, $\mathrm{Zn}$ not only inhibited the development of roots on $T$. portulacifolium stem cuttings completely during the first week of exposure but also reduced the development of roots during later stages as well. This is similar to the observations made in $P$. oleracea and $T$. triangulare stem cuttings where exposure to HMs not only delayed root initiation but also reduced root growth (Mohanapriya et al., 2006; Rajkumar et al., 2009). Jewell (1994) also showed that $\mathrm{Zn}$ could reduce root growth in Festula rubra L. and Calamagrostis epigejos (L.) Roth. The negative influence of $\mathrm{Zn}$ on the development of roots can be due to its influence on the division and elongation of plant cells (Seregin et al., 2011). Although $\mathrm{Zn}$ is involved in the synthesis of tryptophan a precursor of auxin (Tsonev and Lidon, 2012), excess $\mathrm{Zn}$ in roots can influence auxin transport and its distribution in root tips thereby affecting root growth (Zhang et al., 2018). The linear reduction in root length with increasing concentrations of $\mathrm{Zn}$ in the nutrient solution is in line with the observations of Zhang et al. (2018) who showed that high concentrations of $\mathrm{Zn}$ in root tips of Arabidopsis reduced the abundance of PIN4 (peptidylprolyl cis/trans isomerase, NIMA-interacting 4) which is involved in the distribution of auxins thereby inhibiting root elongation. The lack of any significant effect of $\mathrm{Zn}$ at lower concentrations on rooting in $T$. portulacifolium stem cuttings is similar to the findings of Rajkumar et al. (2009) in T. triagulare where only higher concentrations of $\mathrm{Cd}$ was shown to inhibit root growth 
while lower concentrations failed to show any marked effect. The toxic effect of $\mathrm{Zn}$ directly either on the membrane integrity or cell division might have contributed to the reduction in the development of roots on the stem cuttings. Subsequently, the effects of $\mathrm{Zn}$ on respiration, photosynthesis, and synthesis of proteins in roots may also contribute to the retardation of normal root development on the stem cuttings of $T$. portulacifolium (Agarwal et al., 1987). The observed inhibition of root growth indicates the metal penetration and accumulation in roots (Mohanapriya et al., 2006). Roots developed in the presence of $\mathrm{Zn}$ were much paler and finer than those developed in its absence.

Dry mass of the stem, leaves and roots reduced with increasing concentrations of $\mathrm{Zn}$. The suppression of growth and decrease in dry weight of different plant parts is well supported by the results obtained by Kubota and Takenaka (2003). When toxic elements enter plants, the toxic effect of these elements on plant metabolism often results in reduced biomass production. The reduction in plant biomass may occur either at an organ level or on the whole plant (Hagemeyer, 1999; Sadeghzadeh, 2013). The proportion decline in plant biomass was correlated to an increase in the accumulation of $\mathrm{Zn}$ in plant parts. The negative influence of $\mathrm{Zn}$ on plant growth can result from the blocking of the metabolic pathways that are associated with the growth and development of plants due to the direct toxic effects of the HMs (Wierzbicka and Obidzinska, 1998). Although not examined in the present study, high concentrations of $\mathrm{Zn}$ in the plant growth medium are known to compete with plant's uptake of nutrients like phosphorus, $\mathrm{Cu}$, iron, magnesium and manganese causing their deficiencies in plants (Broadley et al., 2007). This could have also contributed to the decline in growth of $T$. portulacifolium stem cuttings with increasing concentrations of $\mathrm{Zn}$ in this study. Tolerance index has been a useful indicator for characterizing plant tolerance to $\mathrm{HMs}$. In $\mathrm{Zn}$, the high $\mathrm{Ti}$ at $40 \mathrm{ppm}(133.68 \%)$ indicates an increase in biomass suggesting that plants express a growth dilution effect due to its tolerance to high $\mathrm{Zn}$ concentrations (Audet and Charest, 2007).

The phytotoxic effect of $\mathrm{Zn}$ was well pronounced in $T$. portulacifolium at high concentrations of $\mathrm{Zn}$ in the nutrient solution. Generally, toxic symptoms become visible when the concentrations of $\mathrm{Zn}$ exceed $300 \mathrm{ppm}$ in the leaves (Broadley et al., 2007). Nevertheless, certain plant species like $T$. portulacifolium as observed in the present study can express toxicity symptoms even at less than $100 \mathrm{ppm}$ of leaf $\mathrm{Zn}$ concentration. The toxicity threshold for $\mathrm{Zn}$ can vary significantly even for the same plant species under different growing conditions and $\mathrm{Zn}$ toxicity at less than $100 \mathrm{ppm}$ plant tissue concentration has been reported in certain crop species (Takkar and Mann, 1978). Studies have shown that leafy vegetables are more sensitive to $\mathrm{Zn}$ toxicity due to their inherent ability to uptake and accumulate high concentrations of $\mathrm{Zn}$ in their tissues (Broadley et al., 2007). Various morphological changes like wilting and withering in addition to the necrotic spots was evident on leaves at high concentrations of $\mathrm{Zn}$. The accelerated senescence in leaves may be due to the increased membrane permeability induced by Zn (Langille and MacLean, 1976). Chlorosis of leaves was also seen at higher concentrations of $\mathrm{Zn}$. This may be due to the reduction in the abundance of the chloroplast due to a decrease in their number per cell or a change in cell size. Baryla et al. (2001) showed that Brassica napus L., growing in HMs contaminated soils induced chlorosis due to the interference of the $\mathrm{HM}$ with chloroplast replication and cell division. The toxicity symptoms of $\mathrm{Zn}$ manifested by the appearance of necrotic spots and chlorosis of leaves, weak development of root branches and browning of roots similar to those induced by Cd toxicity (Das et al., 1997). Koleva et al. (2010) also reported necrotic spots in leaves of Triticum durum Desf., in response to $\mathrm{Zn}$ toxicity.

Higher concentrations of $\mathrm{Zn}$ caused the decay of the stem cutting which started from the base and progressed upwards. The initiation and progress of decay from the cut surface of the stem with increasing exposure time and concentrations of $\mathrm{Zn}$ is similar to the findings reported in $P$. oleracea by Makeshkumar et al. (1996). The initiation of decay in the stem cuttings in response to exposure to high concentrations of HMs has been ascribed to the failure in the functional integrity of cells resulting in microbial colonization and degradation (Rajput and Rao, 2006). Nevertheless, the decay process also depends on the concentrations of the metals and the gradient effect (Klapheck et al., 1994). Pink coloration and disappearance of colour in the metal solution deserve further investigation. However, the pink coloration may be due to the leaching out of plant pigments which were also noted by Rajkumar $e t$ al. (2009).

The accumulation of $\mathrm{Zn}$ in the leaves of $T$. portulacifolium stem cuttings was almost similar or slightly higher than those in the stems at lower concentrations of $\mathrm{Zn}$ exposure (up to $10 \mathrm{ppm}$ ). However, accumulation of $\mathrm{Zn}$ was always higher in the stems than in the leaves exposed to $>10 \mathrm{ppm}$ of $\mathrm{Zn}$. The increased $\mathrm{Zn}$ accumulation as seen in stems and leaves of $T$. portulacifolium with increasing concentrations of $\mathrm{Zn}$ was also observed in Brassica rapa $\mathrm{L}$., exposed to different concentrations of $\mathrm{Zn}$ in a hydroponic system (Coolong et al., 2004). The high Zn content in the leaves of T. portulacifolium was also observed in Salix purpurea L. (Dos Santos Utmazian et al., 2007) which could be due to the high mobility of $\mathrm{Zn}$ in plant parts (Clemens, 2017).

\section{Conclusions}

It can be stated that $\mathrm{Zn}$ studied interfere with the regeneration potential of $T$. portulacifolium by affecting root development and/or their decay. Further studies on the significance of substrate in HMs accumulation would bring more evidence in the phytoremediation of HMs and their effects on the plants.

\section{References}

Agarwal K, Sharma A, Talukder G (1987). Copper toxicity in plant cellular systems.Nucleus 30(2):131-158.

Andrades-Moreno L, CambrolléJ, Figueroa ME, Mateos-Naranjo E (2013). Growth and survival of Halimione portulacoides stem cuttings in heary metal contaminated soils. Marine Pollution Bulletin 75(1-2):28-32. 
538

Antosiewicz DM (1993). Mineral status of dicotyledonous crop plants in relation to their constitutional tolerance to lead. Environmental and Experimental Botany33(4):575-589.

Audet P, Charest C (2007). Heavy metal phytoremediation from a metaanalytical perspective. Environmental Pollution 147(1):231-237.

Babu RK, Vinay K, Sameena S K, Prasad S V, Swapna S, Rao AC (2009). Antihypergycemic and antioxidant effects of Talinum portulacifolium leaf extracts in streptozotocin diabetic rats: A dose-dependent study. Pharmacognosy Magazine 5(9):1-10.

Balkhair KS, Ashraf MA (2016). Field accumulation risks of heavy metals in soil and vegetable crop irrigated with sewage water in western region of Saudi Arabia. Saudi Journal of Biological Sciences 23(1):S32-S44.

Baryla AP, Carrier F, Franck C, Coulomb C, Sahut M and Havaux (2001). Leafchlorosis in oilseed rape plants (Brassica napus) grown on cadmiumpolluted soil: causes and consequences for photosynthesis and growth. Planta212(5-6):696-709.

Broadley MR, White PJ, Hammond JP, Zelko I, Lux A (2007). Zinc in plants. New Phytologist 173(4):677-702.

Castiglione S, Franchin C, Fossati T, Lingua G, Torrigiani P, Biondi S (2007). High zinc concentrations reduce rooting capacity and alter metallothionein gene expression in white poplar (Populus alba L. cv. Villafranca). Chemosphere 67(6):1117-1126.

Clemens S (2017). How metal hyperaccumulating plants can advance $\mathrm{Zn}$ biofortification. Plant and Soil 411(1-2):111-120.

Cobbett C, Goldsbrough P (2002). Phytochelatins and metallothioneins: roles in heavy metal detoxification and homeostasis. Annual Review of Plant Biology 53:159-182.

Conn SJ, Hocking B, Dayod M, Xu B, Athman A, Henderson S, Aukett L, Conn V, Shearer MK, Fuentes S, Tyerman SD, Gilliham M (2013). Protocol: optimising hydroponic growth systems for nutritional and physiological analysis of Arabidopsis thaliana and other plants. Plant Methods 9:4. https://doi.org/10.1186/1746-4811-9-4

Coolong TW, Randle WM, Toler HD, Sams CE (2004). Zinc availability in hydroponic culture influences glucosinolate concentrations in Brassica rapa. Hortscience 39 (1):8486.

Das P, Samantaray S, Rout G (1997). Studies on cadmium toxicity in plants: a review.Environmental Pollution 98(1):29-36.

Das S, Green A (2013). Importance of zinc in crops and human health. Journal ofSAT Agricultural Research 11:1-7.

Dos Santos Utmazian MN, Wieshammer G, Vega R, Wenzel WW (2007). Hydroponic screening for metal resistance and accumulation of cadmium and zinc in twenty clones of willows and poplars. Environmental Pollution 148(1):155-165.

Dushenkov V, Kumar PBAN, Motto H, Raskin I (1995). Rhizofiltration: the use of plants to remove heavy metals from aqueous streams. Environmental Science and Technology 29(5):1239-1245.

FasaniE, Manara A, Martini F, Furini A, DalCorso G(2018).The potential of genetic engineering of plants for the remediation of soils contaminated with heavy metals Plant, Cell and Environment 41(5):1201-1232.

Hagemeyer J (1999). Ecophysiology of plant growth under heavy metal stress. In: Prasad MNV, HagemeyerJ (Eds.) Heavy metal stress in plants; from molecules to ecosystems. Springer-Verlag, Berlin Heidelberg pp 157-181.

Hassanein AMA (2013). Factors influencing plant propagation efficiency via stem cuttings. Journal of Horticultural Science and Ornamental Plants 5(3):171-176.

Hoagland DR, Arnon DI (1950). The water-culture method for growing plants without soil. College of Agriculture, University of California, Berkeley.

Iori V, Pietrini F, Massacci A, Zacchini M (2015). Morphophysiological responses, heavy metal accumulation and phytoremoval ability in four willow clones exposed to cadmium under hydroponics. In: Ansari A, Gill S, Gill R, Lanza G, Newman L (Eds.) Phytoremediation: Management of environmental contaminants. Springer Inter Pub, Switzerland pp 87-98.

Jayanthi P, Senthilkumar P, Sivasankar S (2015). Interactive effects of copper and zinc accumulation in Portulaca olearcea stem cuttings, through hydroponics. Advances in Applied Science Research 6(5):5456.

Jewell W (1994). Resource-recovery wastewater treatment combined anaerobic treatment of primary sewage with hydroponic secondary tertiary treatment. American Scientist 82(4):366-375.

Jones JB Jr (1982). Hydroponics: Its history and use in plant nutrition studies. Journal of Plant Nutrition 5(8):1003-1030.

Klapheck S, Fliegner W, Zimmer I (1994). Hydroxymethylphytochelatins v-glutamylcysteine $(\mathrm{N})$-serine are metal induced peptides in the Poaceae. Plant Physiology 104(4):1325-1332.

Koleva L, Semerdjieva I, Nikolova A, Vassilev A (2010).Comparative morphological and histological study on zinc- and cadmium-treated durum wheat plants with similar growth inhibition. General and AppliedPlant Physiology 36(1-2):8-11.

Kubota H, Takenaka C (2003). Arabis gemmifera is a hyperaccumulator of Cdand Zn. International Journal of Phytoremediation 5(3):197-201.

Kumar A, Prasad MNV (2010). Propagation of Talinum cuneifolium L. (Portulacaceae), an ornamental plant and leafy vegetable, by stem cuttings. Floriculture and Ornamental Biotechnology 4(S1):68-71.

Langille WM, MacLean KS (1976). Some essential nutrient elements in forest plants as related to species, plant part, season and location. Plant and Soil 45(1):17-26.

Lansdown RV (2013). Talinum portulacifolium. Retrieved 2018 August 19 from The IUCN red list of threatened species 2013:e.T13591558A13598358. http://dx.doi.org/10.2305/IUCN. UK.2013-1.RLTS.T13591558A13598358.en.

LiC, Xiao B, WangQH, YaoSH, WuJY (2014). Phytoremediation ofZnand Cr-contaminated soil using two promising energy grasses. Water Air and Soil Pollution 225(7): 2027, https://doi.org/10.1007/s11270014-2027-5

Lone MI, He Z, Stoffella PJ, Yang X (2008). Phytoremediation of heavy metal polluted soils and water: Progresses and perspective. Journal of Zhejiang University Science B 9(3):210-220.

Makeshkumar K, Thangavel P, Subburam V (1996). Effect of heavy metals on the regeneration potential of the stem cuttings of the medicinal plant Portulaca oleracea Linn. Proceedings of Academy of Environmental Biology 5(2):139-144.

Miller AG, Morris M (2004). Ethnoflora of the Socotra Archipelago. Royal 
Botanic Garden Edinburgh, Edinburgh.

Mohanapriya S, Senthilkumar P, Sivakumar S, Dineshkumar M, Subbhuraam CV (2006). Effects of copper sulfate and copper nitrate in aquatic medium on the restoration potential and accumulation of copper in stem cuttings of the terrestrial medicinal plant, Portulaca oleracea Linn. Environmental Monitoring and Assessment 121(13):233-244.

Nagajyoti PC, Lee KD, Sreekanth TVM (2010). Heavy metals, occurrence and toxicity for plants: a review. Environmental Chemistry Letters 8(3):199-216.

Niu Z, Sun L, Sun T, Li Y, Wang H (2007). Evaluation of phytoextracting cadmium and lead by sunflower, ricinus, alfalfa and mustard in hydroponic culture.JES 19(8):961-967.

PiperCS(1966). Soil and plant analysis. Hans Publishers, Bombay, India.

Plum LM, Rink L, Haase H (2010). The essential toxin: Impact of zinc on human health. International Journal of Environmental Research and Public Health 7(4):1342-1365.

Rajkumar K, Sivakumar S, Senthilkumar P, Prabha D, Subbhuraam CV, Song YC (2009).Effects of selected heavy metals ( $\mathrm{Pb}, \mathrm{Cu}, \mathrm{Ni}$ and Cd) in the aquatic medium on the restoration potential and accumulation in the stem cuttings of the terrestrial plant, Talinum triangulare Linn. Ecotoxicology 18(7):952-960.

Rajput KS, Rao KS (2006). Death and decay in the trees of mango (Mangifera indica L.) Microbiological Research162 (3):229-237.

Rout GR, Das P (2003). Effect of metal toxicity on plant growth and metabolism: I. Zinc. In: Lichtfouse E., Navarrete M., Debaeke P. Véronique S., Alberola C. (Eds) Sustainable agriculture. Springer, Dordrechtpp 3-11.

Sadeghzadeh B (2013). A review of zinc nutrition and plant breeding. Journal of Soil Science and Plant Nutrition 13(4):905-927.

Seregin IV, Kozhevnikova AD, Gracheva VV, Bystrova VEI, Ivanov B (2011). Tissue zinc distribution in maize seedling roots and its action on growth. Russian Journal of Plant Physiology 58(1):109-117.

Shahid M, Austruy A, Echevarria G, Arshad M, Sanaullah M, Aslam M, Nadeem M, Nasim W, Dumat C (2014). EDTA-Enhanced phytoremediation of heavy metals: A Review. Soil Sediment and Contamination: An International Journal 23(4):389416.
Takkar PN, Mann MS (1978). Toxic levels of soil and plant zinc for maize and wheat. Plant and Soil 49(3):667-669.

Tchounwou PB, Yedjou CG, Patlolla AK, Sutton DJ (2012). Heavy metals toxicity and the environment. In: Luch A (Ed.) Molecular, clinical and environmental toxicology. Experientia Supplementum, volume 101. Springer, Basel pp133-164.

Tsonev T, Lidon FJC (2012). Zinc in plants-an overview. Emirates Journal of Food and Agriculture 24(4):322-333.

Vysotskaya LB, Cherkoz'yanova AV, Veselov SY, Kudoyarova GR (2007). Role of auxins and cytokinins in the development of lateral roots in wheat plants with several roots removed. Russian Journal of Plant Physiology 54(3):402-406.

WangJ, Tian C, Zhang C, Shi B, Cao X, Zhang T-Q, Zhao Z, WangJ-W, Jiao Y (2017). Cytokinin signaling activates WUSCHEL expression duringaxillary meristem initiation. The Plant Cell 29:1373-1387.

Wang W, Wu Y, Akbar S, Jia X, He Z, Tian X (2016). Effect of heavy metals combined stress on growth and metals accumulation of three Salix species with different cutting position. International Journal of Phytoremediation 18(8):761-767.

Wierzbicka M, Obidzinska J (1998). The effect of lead on seed imbibition and germination in different plant species. Plant Science 137(2):155171.

Wilkins DA (1978). The measurement of tolerance to edaphic factors by means of root growth. New Phytologist 136(3):481-488.

Yanez L, Ortiz D, Calderon J, Batres L, Carrizales L, Mejia J (2002). Overview of human health and chemical mixtures: problems facing developing countries. Environmental Health Perspective 110(S6):901909.

ZhangP, Sun L, Qin J, Wan J, WangR, LiS, XuJ (2018). cGMP is involved in $\mathrm{Zn}$ tolerance through the modulation of auxin redistribution in root tips. Environment and Experimental Botany 147:22-30. 